\title{
Response of Organic \& Inorganic Fertilizers to the Growth, Yield and Soil Nutrient Status in Tomato (Lycopersion esculentum)
}

\author{
Shamsul Islam ${ }^{1}$ \\ F. S. Hamid ${ }^{2}$ \\ Basharat Hussain Shah ${ }^{3}$ \\ Qamar - uz- Zaman ${ }^{4}$ \\ Noorullah Khan ${ }^{5}$ \\ Fayaz Ahmad ${ }^{6}$ \\ Samra Aftab ${ }^{7}$
}

\begin{abstract}
The study was conducted at National Tea \& High value crops Research Institute, Shinkiari during 2015-16. The objective of the experiment was to find out the most effective and economical organic \& inorganic fertilizer for successive growth of tomato. The variety transplanted was SAHIL. The experiment was laid out in RCB design with 3 replications. Different doses of organic fertilizer and inorganic applied per ha were $T_{1}$ Control, $T_{2}$ NPK @ 100:80:60 kg, Ts Farm Yard Manure@20 MT, T* Farm Yard Manure@10MT+NPK@50:40:30 kg,T5.Farm rard Manure@15 MT+ NPK@75:60:40 kg, T6 Poultry Manure@10 MT, T7 Poultry Manure@5MT+NPK@50:40:30kg,TsPoultryManure@7.5 MT+ NPK@75:60:40 kg, Ts Farm Yard Manure@10 MT+ Poultry Manure@5 MT+NPK@50:40:30 kg,.Organic manures in the form of Farm Yard Manure and Poultry manure were applied by side dressing after transplantation while half dose of chemical fertilizers of the total amount was applied at the start of the experiment and the remaining half was applied after $1^{\text {t }}$ irrigation. The observations in respect to increment in plant height, number of branches, number of fruits, fresh fruit weight, total soluble solids, soil $p H$ and \% organic matter recorded. Soil samples representing $0-20$ and $20-40 \mathrm{~cm}$ deep soil analyzed for soil $\mathrm{pH}$, organic matter having soil pH $6.25 \& 6.00$ respectively $\mathcal{E}^{\circ}$ organic matter $2.90 \%$ \& $0.13 \%$ respectively. It was observed that plant height, number of branches, number of fruits, fresh fruit weight and total soluble solids recorded per plant significantly increased with increment of fertilizer dose. However, soil pH slightly increased with application of fertilizer while organic matter also increased with increasing fertilizer rate but remained unchanged in all the treatments.
\end{abstract}

\section{Introduction}

Tomato (Lycopersicon esculentum Mill) belongs to the family Solanaceae. It is one of the most widely eaten vegetables in the world. It can be eaten fresh or in multiple of processed forms Periago, et al. [1]. Revealed that it can prevent from several diseases due to the content of antioxidants including carotenes, (Lycopene as well as $\beta$-carotene), ascorbic acid, and phenolic compounds. It is reported by Isah, et al. [2] that the world production of tomato in 2012 was 145.8 metric tons where China was leading with 41.9 metric tons.

Egypt is the leading producer with the production of 39.5 metric tonnes in Africa, and Nigeria is the fourth and leads in West Africa sub region with an estimated output of 1.10 metric tons and average yield of 10 tons ha ${ }^{-1}[3]$.

The average yield of tomato in Pakistan is 27.43 tons/ha which is very low as compared to other tomato producing countries [4]. It is grown in two season in Khyber Pakhtunkhwa. The summer crops are grown in plain areas, whereas the winter crops are grown in some frost free zones as Bara killey in Peshawar, Malakand Agency and Dargai. It is a major horticultural crop with an estimated global production of over 120 million metric tons [5]. The attraction towards tomato growing is due to its high yielding capacity in a short duration and having high minerals like iron, lycopene and phosphorus [6] and having some vitamins like B and $\mathrm{C}$. Hence the area under tomato cultivation is increasing day by day. The yield potential of tomato crop is affected due to many biotic and abiotic problems. Several bacterial, viral and fungal diseases may seriously 
damage the tomato crop. In Pakistan bacterial wilt is one of the diseases which results huge losses in tomato production every year [7]. It was reported by Khakwani, et al. [8] that higher doses of fertilizers enhanced vegetative growth and delayed flowering.

One of the important factors for better production of tomato is proper use of fertilizers. Nitrogen requirement for the growth the plant is comparatively larger than other elements Marchner [9]. Arya, et al. [10] reported that nitrogen and potassium plays a key role in tomato growth when it is applied during growing stage and phosphorus must be applied after transplanting the tomato plant. Nitrogen promotes plant organs development and result in abundant chlorophyll except root growth that is relatively poor [11] and its deficiency results in stunted growth of the plant, leading to premature flowering and short growth cycle. To achieve maximum yield, timing of fertilizers application and appropriate source is also necessary for improved nitrogen management [12].

It was asserted that inorganic fertilizers can improve crop yields and soil $\mathrm{pH}$, total nutrient content, and nutrient availability, but their use is limited due to scarcity, high cost, nutrient imbalance and soil acidity [13]. It was concluded in a study that maximum yield of tea can be obtained if nitrogenous fertilizer is applied by foliar application@262.5 kg/ha along with basal doses of Phosphorus and Potassium [14]. Green manure has received renewed attention with emphasis on long term sustainability of agricultural system because it can be used as a source of soil nutrients and alternative to maintenance of soil fertility [15] but green manure as a source of soil fertility is not a common practice among vegetable crop production especially tomato in this region. Production of organically grown vegetables has become increasingly popular.

Little research has been conducted using organic fertilizers for transplants. Information regarding use of organic manure, NPK fertilizer and improved tomato varieties is very less. The objective of this study was to evaluate the potential of organic fertilizers with or without combination of inorganic fertilizer for growing tomato transplants. Therefore this research was design to provide the physiological growth of tomato under organic and inorganic fertilizer rate.

\section{Material and Methods}

This experiment was conducted during 2014-15 at National Tea \& High value crops Research Institute, Shinkiari. One month old seedlings were transplanted. The experiment was laid out in RCB design with 3 replications. Organic manures in the form of Farm Yard Manure and Poultry manure were applied by side dressing after transplantation while half dose of nitrogenous fertilizers of the total amount was applied along with phosphoric and potash fertilizer at the start of the experiment and the remaining half dose of nitrogenous fertilizer was applied after $1^{\text {st }}$ irrigation. Nitrogen was applied in the form of ammonium nitrate while Phosphorus \& potassium were applied in the form of Di-ammonium phosphate \& potassium sulphate. The data regarding plant height, number of branches, number of fruits, total soluble solids, fresh fruit weight (per plant), soil pH after harvest and soil organic matter(\%) were recorded. Soil samples representing 0-20 and 20$40 \mathrm{~cm}$ deep soil were collected from the experimental plots before the start of experiment and after harvesting of crops. The soil samples were analyzed for soil pH, Organic matter, soil texture and NPK etc.

\section{Results and Discussion}

The data regarding plant height, No. of branches per plant, No. of fruits per plant, Total soluble solids per plant, fresh fruit weight, soil $\mathrm{pH}$ after harvest and soil organic matter(\%) were recorded.

Plant height: Plant height is a function of genetic and environmental conditions. The data revealed significant difference in plant height among different treatments as the plant height was increasing significantly with the increase and combination of organic \& inorganic fertilizer. However, maximum plant height was obtained in $\mathrm{T}_{9}(26.49 \mathrm{~cm})$ followed by $\mathrm{T}_{8}(25.33 \mathrm{~cm})$ Table 1 while minimum plant height was observed in case of $\mathrm{T}_{0}(20.71 \mathrm{~cm})$. The results are in agreement with the findings of Davis, et al. [16] who reported similar results and increase in plant height. Same results were also obtained by Khan, et al. [17] who observed increase in vegetative growth of plants by application of nitrogen and potash fertilizer.

No of branches per plant: Number of branches per plant also increased significantly with increasing fertilizer dose. Maximum number of branches per plant were found in $\mathrm{T}_{7}$ (5.16) Table 1 followed by $\mathrm{T}_{6}(4.44)$ while minimum no of branches per plant were found in $\mathrm{T}_{0}(2.55)$.

Number of fruits per plant: The number of fruits increased with increasing fertilizer dose. Maximum number of fruits per plant were found in $\mathrm{T}_{9}$ (8.72) Table 1 followed by $\mathrm{T}_{5}$ (7.05) while minimum No. of fruits per plant were observed in case of $\mathrm{T}_{0}(2.61)$.

Fresh fruit weight per plant: Fresh fruit weight means total yield of tomato. The fresh fruit weight affected significantly with increasing level of organic and inorganic fertilizer. Maximum fresh fruit weight per plant was found in $\mathrm{T}_{8}(718.67 \mathrm{gm})$ followed by $\mathrm{T}_{9}(705.67 \mathrm{gm})$ while minimum fresh fruit weight per plant was obtained in $\mathrm{T}_{0}(290 \mathrm{gm})$. However, no significant difference was observed among the treatments. Same results were also obtained by Baskar and Saravanan [18]; Chandraghatgi [19]; Chinnaswami and Marakulandai [20], Chinnaswami and Marakulandai [20] and George, et al. [21].

Total Soluble Solids per plant: Tomatoes are mainly composed of water, soluble and insoluble solids and organic acids, making soluble solid contents and $\mathrm{pH}$ major quality parameters in tomato producing and 
processing industries. The percentage of solids in tomatoes is strongly influenced by a variety of factors, such as e.g. climate, soil type, fertilizer, irrigation, maturity at harvest and postharvest handling. Total soluble solids per plant significantly increased with fertilizer application. Maximum soluble solids per plant obtained in $\mathrm{T}_{9}$ (49.33 $\left.\mathrm{gm}\right)$ followed by $\mathrm{T}_{8}(31.33 \mathrm{gm})$ while minimum total soluble solids per plot obtained in $\mathrm{T}_{0}(21$ $\mathrm{gm})$.

Soil pH after Harvest: Soil pH refers to potential hydrogen, or the hydrogen ion concentration of soil. $\mathrm{pH}$ is a measure of soil acidity. Tomatoes prefer a more acidic soil, $\mathrm{pH}$ 6.0-6.8. Soil pH slightly increased with increasing of fertilizers. However, highest soil $\mathrm{pH}$ was observed in $\mathrm{T}_{3}$ followed by $\mathrm{T}_{6}$ and $\mathrm{T}_{9}$ while minimum soil $\mathrm{pH}$ was found in case of $\mathrm{T}_{1}$.

Soil Organic matter: In a healthy soil with adequate organic matter, plants continue to grow at pH levels that would stunt growth in leaner soils. Increasing soil organic matter means to increase plants' tolerance for acidic or alkaline conditions. The data recorded after harvest Table 1 revealed that organic matter did not increased with increase of fertilizer dose. However, maximum percent of organic matter (3.50\%) was observed in case of $\mathrm{T}_{9}$ followed by $\mathrm{T}_{6}(3.41 \%)$ while minimum organic matter was observed in $\mathrm{T}_{1}$ (control).

\begin{tabular}{|c|c|c|c|c|c|c|c|}
\hline Treatment & $\begin{array}{l}\text { Plant } \\
\text { height } \\
(\mathrm{cm})\end{array}$ & $\begin{array}{l}\text { No. of } \\
\text { branches } \\
\text { /plant }\end{array}$ & $\begin{array}{l}\text { No.of } \\
\text { fruits/plant }\end{array}$ & $\begin{array}{l}\text { Fresh Fruit } \\
\text { weight/plant } \\
(\mathrm{gms})\end{array}$ & \begin{tabular}{|l} 
Total \\
Soluble \\
Solids/plant \\
(gms)
\end{tabular} & $\begin{array}{l}\text { Soil pH } \\
\text { (after } \\
\text { harvest) }\end{array}$ & $\begin{array}{l}\% \\
\text { Organic } \\
\text { matter } \\
\text { (after } \\
\text { harvest) }\end{array}$ \\
\hline $\mathrm{T}_{1}$ & $20.71 \mathrm{~b}$ & $2.55 \mathrm{e}$ & $2.61 \mathrm{e}$ & $290.00 \mathrm{c}$ & 21.0obcd & $6.12 \mathrm{~b}$ & $2.36 \mathrm{~b}$ \\
\hline $\mathrm{T}_{2}$ & $21.16 \mathrm{ab}$ & 2.99de & 3.83cde & $304.00 b c$ & 13.00cd & $6.22 \mathrm{ab}$ & $2.93 \mathrm{ab}$ \\
\hline $\mathrm{T}_{3}$ & $22.44 \mathrm{ab}$ & $3.38 \mathrm{cde}$ & 3.50de & 499.33abc & $9.66 \mathrm{~d}$ & $6.35 \mathrm{a}$ & $3.19 \mathrm{a}$ \\
\hline $\mathrm{T}_{4}$ & $24.88 \mathrm{ab}$ & $3.27 \mathrm{cde}$ & $5.50 \mathrm{obc}$ & $460.67 \mathrm{abc}$ & $19.33 \mathrm{bcd}$ & $6.19 \mathrm{ab}$ & $3.19 \mathrm{a}$ \\
\hline $\mathrm{T}_{5}$ & $22.88 \mathrm{ab}$ & $3.49 \mathrm{~cd}$ & 7.05ab & $525.33 \mathrm{abc}$ & $11.00 d$ & $6.25 \mathrm{ab}$ & $3.31 \mathrm{a}$ \\
\hline $\mathrm{T}_{6}$ & $21.88 \mathrm{ab}$ & $4.44 a b$ & $5.38 \mathrm{bcd}$ & $505.00 a b c$ & $31.33 \mathrm{~b}$ & $6.32 \mathrm{ab}$ & $3.41 \mathrm{a}$ \\
\hline$\overline{T_{7}}$ & $22.99 \mathrm{ab}$ & $5.16 \mathrm{a}$ & $5.49 \mathrm{bc}$ & $632.67 \mathrm{abc}$ & $22.66 \mathrm{bcd}$ & $6.22 \mathrm{ab}$ & $3.37 \mathrm{a}$ \\
\hline $\mathrm{T}_{8}$ & $25.33 \mathrm{ab}$ & $3.83 \mathrm{bcd}$ & $6.94 \mathrm{ab}$ & $718.67 \mathrm{a}$ & $26.66 \mathrm{bc}$ & $6.26 \mathrm{ab}$ & $3.22 \mathrm{a}$ \\
\hline $\mathrm{T}_{9}$ & $26.49 \mathrm{a}$ & $3.94 \mathrm{bc}$ & $8.72 \mathrm{a}$ & $705.67 \mathrm{ab}$ & $49.33 \mathrm{a}$ & $6.32 \mathrm{ab}$ & $3.50 \mathrm{a}$ \\
\hline $\mathrm{CV}$ & 13.62 & 14.75 & 20.99 & 37.99 & 36.15 & 1.97 & 1.97 \\
\hline LSD & 5.47 & 0.94 & 1.98 & 339.05 & 14.18 & 0.21 & 0.64 \\
\hline
\end{tabular}

Source: National Tea \& High value crops Research Institute, Shinkiari.

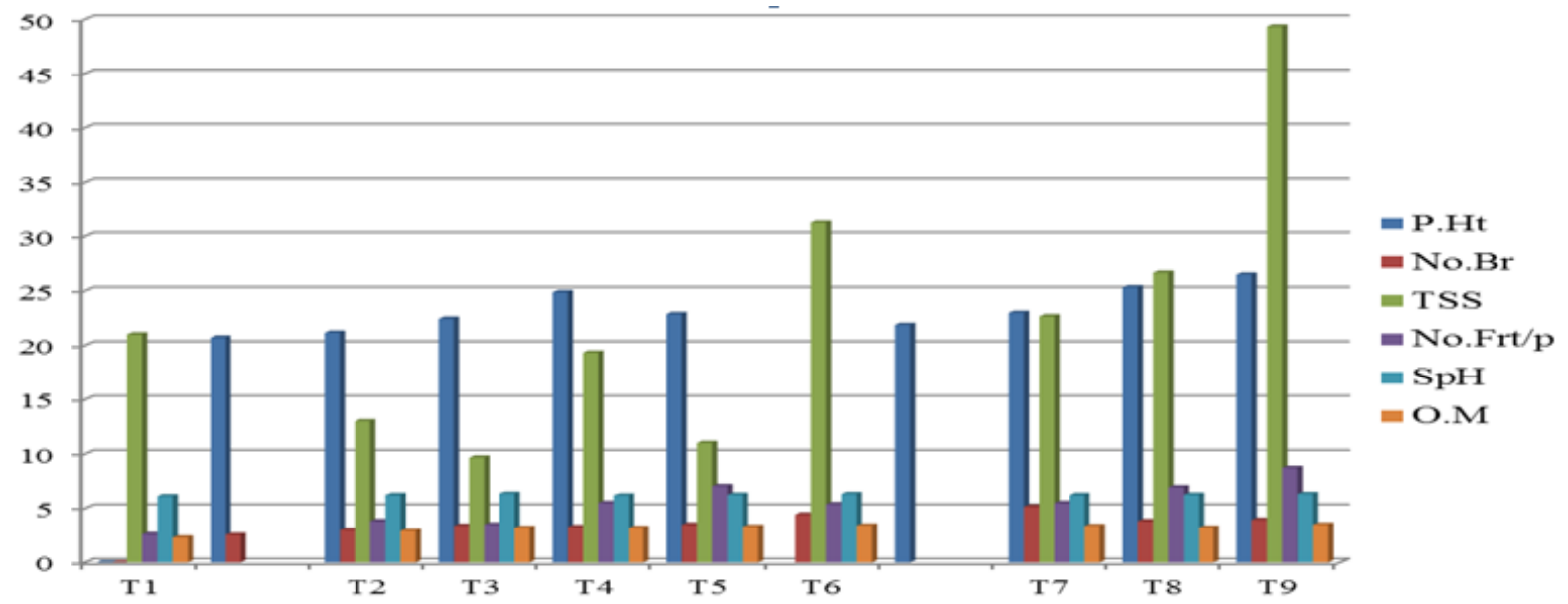

Figure-1. Effect of organic and inorganic fertilizers on physical characteristics of soil and growth of tomato. Source: National Tea \& High value crops research Institute, Shinkiari.

\section{Conclusion}

Results showed that use of FYM, Poultry manure and NPK considerably increased the the growth parameters. Among the treatments studied combination of organic and inorganic fertilizer is best for growth, fruiting and yield of tomato

Based on the results of study it is concluded that organic and inorganic fertilizer improved growth, and increased yield of tomato. The deficiencies of nutrients are impeding the crops yield around the globe; therefore, the endowment of these essential nutrients not only fulfils the nutritional requirements of tomato crop but is also helpful in increasing the growth and yield of tomato. An organic manure fertilizer is a good efficient amendment for improving the physical, chemical and nutritional properties of the soil and increasing crops yield. Among various treatments, Farm Yard Manure@10 MT+ Poultry Manure@5 MT+ NPK@50:40:30 kg is more 
effective in increasing plant height, fruit weight, TSS and yield of tomato and increasing the organic matter in soil.

\section{References}

[1] M. J. Periago, F. J. Garcia-Alonso, K. Jacob, A. B. Olivares, M. J. Bernal, M. D. Iniesta, C. Martinez, and G. Ros, "Bioactive compounds, folates and antioxidant properties of tomatoes (Lycopersicum esculentum) during vine ripening," International Journal of Food Sciences and Nutrition, vol. 60, pp. 694-670, 2009.

[2] A. S. Isah, E. B. Amans, E. C. Odion, and A. A. Yusuf, "Growth rate and yield of two tomato varieties (Lycopersicon esculentum Mill) under green manure and NPK fertilizer rate Samaru Northern Guinea Savanna," International Journal of Agronomy, vol. 48, pp. 49-57, 2014.

[3] FAO, "Faostat." Retrieved from http://faostat.fao.org/site/339/default.aspx, 2012.

[4] MINFA, "Agricultural statistics of Pakistan. Ministry of food, agriculture, and livestock," Food and Agric (Economic Wing), Islamabad, 2005.

[5] FAO, "Food and agricultural organization stat, core production 2005." Retrieved from http://faostat.fao.org/site/340/default.aspx, 2007.

[6] S. D. Bagal, G. A. Sheikh, and R. N. Adsule, "Influence of different levels of N, P and K fertilizers on the yield and quality of tomato," Journal of Maharashtra Agricultural Universities, vol. 14, pp. 158-160, 1989.

[7] I. V. Ruben, "Tomatoes in the tropics. Boulder, Colorado," Western Press, p. 5, 1999.

[8] A. A. Khakwani, U. K. Saddozai, I. U. Awan, M. S. Baloch, Q. Khan, M. Munir, and I. Bakhsh, "Effect of organic and inorganic inputs on soil parameters and productivity of coarse rice (Oryza sativa L. cv. IR-9)," Journal of Agricultural Research, vol. 54, pp. 195-205, 2016.

[9] H. Marchner, "Mineral nutrition in higher plants," ed London, UK: Acad. Inc, 1995, p. 887.

[10] P. S. Arya, Vidyasagar, and S. R. Singh, "Effect of N, P and K on tomato seed production," Scientia Horticulturae, vol. 6, pp. 89-91, 1999.

[11] T. Lincoln and Z. Edvardo, "Assimilation of mineral nutrition. In: Plant physiology," 4th ed Sunderland: Sinaur Associates, Inc. Pub, 2006, p. 705

[12] G. J. Hochmuth, K. D. Shuler, R. L. Mitchell, and P. R. Gilreath, "Nitrogen crop nutrient requirement demonstrations for mulched pepper in Florida," Proceedings of the Florida State. Horticulture Society, vol. 100, pp. 205- 209, 1987.

[13] W. B. Akanbi, A. O. Togun, A. J.A., and E. A. O. Ilupeju, "Growth, dry matter and fruit yields components of okra under organic and inorganic sources of nutrients," American- Eurasian Journal of Sustainable Agriculture, vol. 4, pp. 1-13, 2010

[14] S. U. I. Qamar-uz-Zaman, F. S. Hamid, F. Ahmad, and S. Aslam, "Effect of foliar applied nitrogenous fertilizer on growth and yield of tea (Camellia sinensis L.)," Journal of Agricultural Research, vol. 54, pp. 185-194, 2016.

[15] M. Ali, "Evaluation of green manure technology in tropical lowland rice systems," Field Crops Research, vol. 61, pp. 61-78, 1999.

[16] J. M. Davis, D. C. Sanders, P. V. Nelson, L. Lengnick, and W. J. Sperry, "Boron improves growth, yield, quality, and nutrients contents of tomato," Journal of American Society for Horticultural Science, vol. 128, pp. 441-446, 2003.

[17] A. A. Khan, Inamullah, and M. T. Jan, "Impact of various nitrogen and potassium levels and application methods on grain yield and yield attributes of wheat," Sarhad Journal of Agriculture, vol. 30, pp. 35-46, 2014.

[18] M. Baskar and A. Saravanan, "Effect of coir pit containing potting medium and methods of fertilizers application on yield and quality of tomato," South Indian Horticulture, vol. 46, pp. 200-202, 1998.

[19] S. P. Chandraghatgi, "Performance of Arbuscular mycorrhizal fungi in chilli (Capsicum annuum L.) and tomato (Lycopersicon esculentum Mill.)," Ph.D. Thesis, University of Agricultural Sciences, Dharwad, KARNATAKA (India), 1997.

[20] K. N. Chinnaswami and K. A. Marakulandai, "Influence of organic and inorganic manures on the firmness and storage life of tomatoes," South Indian Horticulture, vol. 15, pp. 36-42, 1967.

[21] R. A. T. George, R. T. Stephons, and S. Varis, The effect of nutrients on the yield and quality of seed in tomato. In Seed Production (Ed.) Hebbleth W P. D.: Butter Worthm London, Boston, 1980. 